Золтан Ђере

Универзитет у Новом Саду

Филозофски факултет

zoltan.gyore1@gmail.com
Оригиналан научни рад

примљено: 27. април 2013

прихваћено: 1. октобар 2013

\title{
БАЧКА ВАРОШКА НАСЕЉА ПРЕМА ЗЕМАЉСКОМ ПОРЕСКОМ ПОПИСУ ИЗ 1828. ГОДИНЕ
}

Сажетак: Рад је посвећен анализи привредних и демографских одлика слободних краљевских градова и трговишта Бачко-бодрошке жупаније на основу података Земаљског пореског пописа из 1828. и пописа становништва који је саставио Лајош Нађ 1827. године. У студији су анализирани демографски, конфесионални и етнички односи, као и карактеристичне црте пољопривредне производње, занатства, трговине, тржишних центара, имовног стања и нека питања друштвене стратификације посматраног становништва.

Кључне речи: Хабзбуршка монархија, Краљевина Мађарска, Војводина, демографија, статистика, занатство, трговина, пољопривредна производња, слободни краљевски градови, трговишта.

Циљ студије је да у кратким цртама прикаже демографске и привредне одлике бачких варошких насеља на основу података Земаљског пореског пописа из 1828. године ${ }^{1}$ и пописа становништва базираном на црквеним шематизмима који је саставио Лајош Нађ 1827. године. ${ }^{2}$ Реч је о два вредна и садржајна пописа који истраживачима омогућују не само нијансирање досадашњег знања него и стицање нових сазнања о демографским и привредним одликама посматраних насеља.

\footnotetext{
* Истраживања на овој теми вршена су у склопу пројекта Филозофског факултета Универзитета у Новом Саду под насловом Војводина - мултиетнички историјски простор, који је финансирало Министарство за науку Републике Србије. Рад је знатно проширена и дорађена верзија реферата саопштеног на Међународном скупу A Magyar Tudomány Napja a Délvidéken, одржаном у Новом Саду новембра 2011. године.

1 VII законски члан Државног сабора Мађарске о „земаљском попису с циљем исправљања порти” [фискална мерна јединица]. На мађарском: „1827. évi VII. törvénycikka porták megigazitására szolgálandó országos összeirásról.“

${ }^{2}$ Nagy Ludovicus, Notitae politico-geographico-statisticae inclyti Regni Hungariae partiumque adnexarum, III, Buda 1828-29.
} 
Комбинација поменута два пописа је могућа због готово идентичног времена њиховог настанка, а њихова паралелна употреба пружа додатне елементе за анализу. Приметимо да је мало савремених европских држава располагало толико садржајним и вредним скупом пописа. Ипак, оба пописа имају и мане: попису Лајоша Нађа недостаје систематичност земаљског пописа, а конскрипција из 1828. г. је уз сву методолошку разрађеност и прецизност за историчаре ипак мањкава, јер у њен видокруг улази само опорезовано становништво, односно изостају племство, црква и друге категорије ослобођене пореске обавезе.

С обзиром на то да је у време пописа већ дуже времена постојала профитно оријентисана племићка, али и сеоска пољопривредна производња, највише нам недостају подаци који би се односили на поседе властеле. Било би интересантно знати у којој мери су бачки племићи прешли на модерне агротехничке и организационе методе, односно, колико њих је производило за тржиште и у којем обиму. Ово би било добро знати и с обзиром на чињеницу да је 1834. године Бачкободрошка жупанија спадала међу малобројне мађарске жупаније које су опонирале политичком и друштвеном програму мађарске либералне опозиције. Слично, можемо само жалити што пореске власти нису биле заинтересоване за неурбаријална пољопоривредна земљишта (крчевине, ремененцијалне земље), ни за закупљене оранице, ливаде и винограде у поседу сељаштва, јер би ти подаци значајно проширили наша сазнања о реалном имовном стању становништва као и истинском интензитету пољопривредне производње.

У том смислу, важно је имати на уму да подаци пописа могу сведочити само о минималним вредностима како у погледу демографских односа тако и у погледу материјалних и духовних добара, развијености привредних и друштвених односа, и да су у стварности постојале осетно диференцираније релације, да је обим производње био знатно већи, а имовно стање сељаштва повољније од оног о којем пописи сведоче.

\section{Опште прилике}

Педесетак година које су претходиле нашим пописима донеле су Хабзбуршкој империји значајне промене. Идеје просветитељства и Францсуке револуције, односно индустријска револуција на Западу Европе и дуготрајни Наполеонови ратови показали су се веома плодотворним у идејној и економској сфери Монархије. Поменуте околности су, уз брзо повећање броја становника, почетке урбанизације, ширење реформистичких идеја и конјунктуре изазване Наполеоновим ратовима (стална велика потражња за прехрамбеним производима, ратном опремом, вуном, рудама, дуваном и металуршком робом), подстакли промене које су учиниле неопходним грађански преображај друштва. У све ширим круговима становништва се ширило уверење да се уз нове идеје, новим начинима привређивања може трајно осигурати виши животни стандард него уз феудалне друштвене и економске оквире. Публиковање извештаја комисије Мађарског државног сабора сачињеног на основу података конскрипције из 1828. г. и расправа у вези са извештајем на државном сабору и конгрегацијама жупанјија, усмеравали 
су јавност у горепоменутом правцу.

Модернизована производња најефикасније се могла применити на великим поседима, те су на тржишну оријентисану масовну производњу прво прешли велики коморски поседи и велепоседничка аристократија, с тим да је погодности модернизације временом успело искористити племство и горњи слојеви сељаштва. Истина, промене су узроковале и негативне појаве: властела се с циљем повећања својих прихода трудила да што више увећа површину својих поседа, што се по правилу дешавало на терет сељаштва.

Демографски односи

Наша истраживања односе се на три слободна краљевска града (Суботица, Нови Сад и Сомбор) и тринаест вароши (Кањижа, Сента, Стари Бечеј, Апатин, Бездан, Станишић, Оџаци, Бачка Паланка, Бачка Топола, Кула, Темерин и Футог). У тим насељима живело је више од једне трећине становништва Бачко-бодрошке жупаније. ${ }^{3}$

Да бисмо могли реално сагледати интензитет и обим развоја до времена пописа, добро је знати од чега се полазило после Карловачког и Пожаревачког мира. Од близу 500 разних насеља колико их је било у другој половини 15. века, ${ }^{4}$ крај османског раздобља доживело је само туце њих, а и та насеља су била заостала у односу на средњовековне демографске и привредне прилике. Бачка је почетком 17. века била напуштена, некултивисана, дуготрајним ратовањима разорена мочварна, једва насељена област. Стотинак година касније у Бачкој је пописано 108 насеља, са живом пољопривредном производњом, лепо обрађеним ораницама, виноградима и воћњацима; са преко сто хиљада оваца, десетине хиљада грла стоке и коња, динамичном трговином, бројним занатлијама; са црквама, касарнама и другим јавним зградама грађеним претежно у барокном стилу и са становништвом чији је културни ниво одговарао савременим приликама. Развој је био изразито видљив.

Бачко-бодрошка је била најмногољуднија од јужноугарских жупанија. Број становника се од Пожаревачког мира брзо повећавао и са почетних тридесетак хиљада, до 1827. г., достигао је 435.237 житеља. ${ }^{5}$ Они су живели у три слободна краљевска града, 13 трговишта, 94 села и 35 насељених пустара. Ова насеља су се знатно разликовала међусобно по броју становника, правном статусу, као и по својој улози у привредном, културном и административном животу.

Најупадљивије су биле разлике у величини насеља: у три слободна краљевска града живело је укупно 72.689 становника (близу 17\% становништва жупаније). У Суботици 34.924, у Новом Саду 20.231 и у Сомбору 17.534 становника. Величина градова је знатно превазилазила величину вароши и села, а истицала се и у земаљским размерама. Бројност становништва нарочито је видљива у поређењу са суседним балканским областима: Београд је 1834 . имао 18.000 , а четрдесет година

\footnotetext{
${ }^{3}$ Zoltán Györe, Gradovi i varoši Bačke početkom XIX veka, Novi Sad 2007, 192.

${ }^{4}$ Borovszky Samu, Bács-Bodrog megye története, I, Budapest 1909, III.

${ }^{5}$ K. Čobanović, A. Hegediš, Demografska i agrarna statistika Vojvodine 1767-1867, Novi Sad $1991,31$.
} 
касније још увек само 27.605 становника. На хрватским територијама су чак и 1857. године постојала само три насеља са више од 10.000 становника (Осијек, Ријека и Загреб). У Бачкој је у време пописа било 6 насеља са више од десет хиљада душа (Баја, Суботица, Сомбор, Нови Сад, Стари Бечеј и Сента); а у 21 насељу било је више од 5.000 становника, при чему је 6 насеља имало статус села (Ада, Мол, Бачко Петрово Село, Сентомаш, Бачки Петровац и Сивац). ${ }^{6}$

За Бачку су била карактеристична насеља са преко 2.000 становника, чак је $71 \%$ свих насеља спадало у ту категорију. Истовремено, у Торонталској и Сремској жупанији већина насеља (61\% односно 92\%) имала је испод 2.000 житеља. Досељеници у Бачку скрасили су се у мањем броју релативно великих места, што је резултирало испотпросечном густином насеља: док је земаљски просек износио 6,5 насеља по квадратном километру, тај однос је у Бачкој био 1,6, с тим да је према југу густина насеља расла. ${ }^{7}$ У литератури се мала густина насеља обично сматра једном од последица османске власти. ${ }^{8}$ Ниска густина насеља је, између осталог, резултирала праксом грађења салаша, некад толико карактеристичних за бачке области, а данас готово несталих. У 18. и 19. веку, да не би морали сваки дан враћати стоку са далеких испаша у село, сељаци су на локацијама удаљеним од насеља градили привремена или трајна станишта, салаше, на којима су чували стоку или гајили житарице и воће. Газде су најчешће само крај недеље проводили у својим селима или градовима. Често се дешавало да су своје куће у насељима, ради чувања преко недеље, поверавали желирима без куће. Настанак салаша био је подстакнут чињеницом да су салаши били ослобођени пореза, односно да се на салашима од очију пореских власти и комшија могао сакрити добар део стоке, који је требало да буде пописан у насељу. Власти су узастопним претњама рушењем покушале да зауставе грађење салаша. ${ }^{9}$ Године 1828. у Суботици је уз а 4.567 градских кућа пописано и 2.197 салаша (32,5\%), у Сомбору уз 2.201 градску кућу било је 1.358 салаша $(38,2 \%) .^{10}$

Савременици су у 19. веку Бачку и Банат сматрали етнички најшаренијом облашћу Мађарске. Они су ту специфичност делом сачували до данашњег дана. У супротности са ситуацијом у Сремској и Торонталској жупанији и Војној граници, где је већина становништва (60-91\%) припадала православној вероисповести, две трећине верника у Бачкој исповедало је католичку веру. Православни су у Бачкој чинили $24 \%$ становника, протестанати $9 \%$, а Јевреји $1,3 \%$. У Бачкој је од војвођанских области живело највише протестанта (37.358, што је срачунато на

\footnotetext{
${ }^{6}$ Zoltán Györe, Gradovi i varoši Bačke, Novi Sad 2007, 34.

7 Золтан Ђере, Демографски односи Војводине на основу пописа Лајоша Нађа из 1828. године, Зборник Матице српске за историју, 46, Нови Сад 1993, 103-104.

${ }^{8}$ Према подацима пописа Лајоша Нађа густина становника Бачко-бодрошке жупаније 1827. г. била је 46,3 становника по квадратном километру. Према попису становништва из 2011. г. просек густине становништва за Војводину износи приближно двоструко (Попис становнштва, домаћинства и станова y Републици Србији 2011. године, Републички завод за статистику ISSN 0354-3641, Билтен - Републички завод, COBISS.SR-ID 16405506, Београд 2011, 22).

${ }^{9}$ Антал Хегедиш, Успон градске привреде, Домети, бр.100-103, 67-68.

${ }^{10}$ Архив Војводине, збирка микрофилмова, „Попис према VII законском члану из 1827.године”, N 60 és N 64 , „Observationes“.
} 
данашњу територију Војводине 61\%) и Јевреја (од пописаних 7.440 Јевреја њих 5.750, или 77\%). Поменимо да су од 108 бачких насеља Јевреји забележени у 90, православни у 85, протестанти у 65 а католика је било у сваком од бачких насеља. Католици су били у релативној већини у 52 места. Већина Јевреја је живела у градовима и варошима $(55,2 \%)$, а у Боршоду и Бачкој Паланци био је највећи однос Јевреја (5,3\% становника) према укупном становништву. Претежан део протестаната (94,6\%) живело је по селима. ${ }^{11}$

За Бачко-бодрошку жупанију је било карактеристично да су у сваком месту, сем у три насеља (Бајша, Бачка Паланка и Селенча), представници једне од конфесија чинили апсолутну већину. Православни су били у апсолутној већини у Новом Саду, Сомбору, Станишићу, Тителу и Старом Бечеју, док су католици били у већини у осталим насељима. ${ }^{12}$ Према подацима Елека Фењеша, 37,7\% становника били су Мађари, 20,4\% Срби, 19\% Немци, 18,1\% Буњевци, Шокци, 2,1\% Словаци, 1,6\% Јевреји, а живело је овде још и Грка, Русина, Јермена, Цигана и припадника других народности. ${ }^{13}$

Друштвена стратификација становништва градова и вароши

Реалан социјални положај сваког становника зависио је од његове улоге у друштвеној подели рада, занимања и делом од правног статуса. Помислимо само на положај стотине хиљада ситних племића: без обзира на њихов привилегован правни положај, многи од њих су се бавили земљорадњом, превозом, били су крчмари, адвокати наставници или други припадници професионалне интелигенције.

Друштвена и професионална структура становништва Бачке добрим делом се подударала са земаљским, доминантно пољопривредним карактером, с тим да се у посматраним варошким и градским насељима примећују знаци почетака урбанизације. Нажалост, анализирани пописи и у овом случају пружају углавном индиректне информације.

У посматраних 16 насеља, у просеку 23\% пописаних били су кметови, $41,9 \%$ желири (при чему треба приметити да су у категорију желира у градовима убрајали све газде које нису имале грађанско право, али су поседовали некретнине), $12 \%$ били су желири без куће (укупно значи сразмера кметова разне категорије износила је близу 77\%), 8,9\% грађани, 2,7\% трговци, $12 \%$ занатлије, $1 \%$ хонорациори (професионална интелигенција), а у за 6\% пописаних старешина није дефинисано занимање. ${ }^{14}$

Положај кметова у Бачко-бодрошкој жупанији је био специфичан с обзиром на то да је највећи властелин била Мађарска дворска комора, под чијом јурисдикцијом је било више од половине житеља жупаније. Ситуација кметова на коморским властелинствима је била повољнији од оних на приватним

\footnotetext{
11 3. Ђере, Демографски односи Војводине на основу пописа Лајоша Нађа из 1828. године, 106-107, 111.

${ }^{12}$ Z. Györe, Gradovi i varoši Bačke, 35-36.

13 3. Ђере, Демографски односи Војводине на основу пописа Лајоша Нађа из 1828. године, 111.

${ }^{14}$ Z. Györe, Gradovi i varoši Bačke, 62-63.
} 
властелинствима, јер су обавезе биле бројно мање и блаже, а правна сигурност стабилнија. Коморска земљишта су била организована у 4 провизората (сомборски, сантовски, кулски и паланачки) са седиштем у Сомбору. Коморски чиновници, провизори, бележници, инжењери и други, обављали су важне задатке: водили су бригу о управљању коморским поседима, трудили су се да примењујући меркантилистичке принципе унапреде привредни живот жупаније; руководили су сложеним послом колонизације Бачке. ${ }^{15}$ Комора је имала јурисдикцију и над Потиским крунским дистриктом са више десетине хиљада становника.

Уз Комору, у Бачкој је било 12 већих и мноштво мањих приватних властелинства. Поменимо нека познатија: трговиште Бач припадало је калочком надбискупу, Футог породици Брунсвик, Бачка Топола породици Крај, Станишић баронима Редл, Баја Грашалковићима, а Кула породици Стратимировић. У Бачкободрошкој жупанији је 1785. живело 3.200, а 1847.г. 14.108 племића. ${ }^{16}$

Пописи из 1786,1828 . и 1847 . године, као и савремени извештаји, сведоче о повећању броја кметова и кметовских порти (при чему је број кметова растао знатно брже); о уситњавању сељачких газдинстава и сиромашењу кметова, односно о повећању властелинских поседа на терет заједничких или кметовских земљишта. Као и другде у јужним областима Мађарске, услед уситњавања газдинстава расла је сразмера желира у односу на сразмеру кметова. Генерално гледано, у најбољем положају су били немачки кметови, јер су већином били подложници Коморе, а традиционалан начин наслеђивања је код њих ишао у прилог очувању целовитости сељачких поседа: земљу је наслеђивао само најстарији син, док су остали морали да се одлуче за војни позив, да изуче занат или да се определе за свештеника, итд. Ова пракса је ефективно спречавала уситњавање поседа, што је било обична појава у мађарским, српским, румунским и другим сељачким породицама. Као илустрација нека послуже савремене статистике, које показују да је на 100 кметовских поседа код не-Немаца долазило по 400 кметова, а у случају Немаца само 60! Сагласно с тим, приходи немачких кметова су били приметно виши. ${ }^{17}$

Пошто су у градовима међу желире сврстали све пописане старешине које нису имале грађанско право, али су располагали опорезивању подложном имовином, становништва вароши и градова не смемо рачунати заједно при утврђивању броја желира и кметова. Посматрано по типу насеља, можемо констатовати, да је у градовима пописано укупно 5.878 „желира“ (39,4\% свих пописаних старешина) и 2.114 (14,1\%) желира без куће. У трговиштима било је 6.194 (41,4,\% свих пописаних старешина) кмета, 5.369 (35,9\%) желира и 1.145 (7,7\%) желира без куће, слугу $(3,1 \%$, у питању су по свој прилици били радници који су помагали у пољопривредним пословима), $12 \%$ били су хонорациори, слушкиње, занатлије и трговци. Удео желира бескућника је у оба типа насеља доста велик и можемо се само надати да је то барем делимично резултат методологије пописивања. Могуће је

\footnotetext{
15 Антал Хегедиш, Управни, друштвени, духовни и културни центар, Домети, бр. 100-103, Сомбор 2000, 107-108.

${ }^{16}$ Z. Györe, Gradovi i varoši Bačke, 37.

17 Антал Хегедиш, Литература прве половине 19. века о привреди Торонталске, Бачко-Бодрошке и Сремске жупаније, Зборник Матице српске за историју, 21, Нови Сад 1980, 112-113.
} 
и да су неки од њих располагали некретнинама на салашима. ${ }^{18}$

Сразмера неаграрног становништва може послужити као посредан показатељ привредних промена у правцу модернизације, грађанског преображаја и почетака урбанизације. Нажалост, порески попис из 1828. г. не садржи податке у вези са свим припадницима неаграрних занимања, па тако не знамо нпр. број племића, свештенства, одслужених војника, разних чиновника, превозника, лађара, циглара, лучких радника, итд., иако је таквих на нашим просторима било у приметном броју. Познат нам је број грађана, хонорациора, занатлија, слушкиња и трговаца.

У три слободна краљевска града било је укупно 2.379 становника са статусом грађана, што чини 15,8\% свих старешина градова (земаљски просек је био $13,8 \%$ ). Релативно мали проценат грађана може бити резултат чињенице да у првој половини 19. века поседовање права грађана више није био услов бављења трговином и занатима, нити услов за поседовање земље. Ипак, било је оних који нису штедели новац да стекну грађански статус, пошто су само на тај начин били ослобођени плаћања царине, стицали право да учествују у управљању градом, односно да имају висок друштвени углед. Историјски извори сведоче о томе да су слободни краљевски градови у нашој области имали главну улогу у подстицању привредног живота, с тим да су поједине вароши, као што су нпр. Сента, Кула, Бачка Паланка, Апатин, Турски Бечеј, Велики Бечкерек па и понеко село, располагале бројним становништвом, тржишним вишковима и значајном трговином. ${ }^{19}$

Доња табела приказује сразмеру слушкиња, хонорациора, занатлија и трговаца у односу на број пописаних старешина. Грађане нисмо уврстили у табелу, с обзиром на то да у попису има преклапања у броју хонорациора, занатлија и трговаца с једне стране, и грађана, с друге стране.

\begin{tabular}{||l||c||}
\hline \multicolumn{1}{|c|}{ Место } & $\begin{array}{c}\text { Сразмера слушкиња, хонорациора } \\
\text { занатлија и трговаца према броју старешина }\end{array}$ \\
\hline \hline Нови Сад & $31,9 \%$ \\
\hline Апатин & $23,2 \%$ \\
\hline Бач & $19,2 \%$ \\
\hline Суботица & $19,0 \%$ \\
\hline Стари Бечеј & $17,8 \%$ \\
\hline Бездан & $17,8 \%$ \\
\hline Кула & $17,7 \%$ \\
\hline Сента & $16,5 \%$ \\
\hline Сомбор & $16,3 \%$ \\
\hline Б. Паланка & $15,6 \%$ \\
\hline Оџаци & $13,2 \%$ \\
\hline Футог & $12,9 \%$ \\
\hline Кањижа & $12,6 \%$ \\
\hline Темерин & $11,2 \%$ \\
\hline Б. Топола & $7,4 \%$ \\
\hline Станишић & $6,7 \%$ \\
\hline \hline
\end{tabular}

\footnotetext{
${ }^{18}$ Z. Györe, Gradovi i varoši Bačke, 192-195.

${ }^{19}$ На основу података пописа, Архив Војводине, Збирка микрофилмова, Н 58 - Н 64.
} 
Пошто ћемо касније детаљније говорити о трговцима и занатлијама, овде ћемо изложити само неколико запажања у вези са хонорациорима. Попис садржи само број хонорациора који су располагали имовином подложном опорезивању (адвокати, лекари, бабице, инжењери, професори, итд.), али не и свих припадника интелигенције.

Хонорациори су сматрани вишим друштвеним слојем и њихово присуство у неком насељу је било важно, јер су задовољавали основне образовне, религијске, управне, правосудне и културне потребе становништва. Доприносили су јачању централних функција места и њихово присуство обично је подстицајно деловало и на процес урбанизације; просечно добар имовни положај и њихове специфичне потребе учинили су их захтевним клијентима занатлија и дућанџија и уједно су дали замајац делатности књижара, штампарија, позоришта и других услужних делатности. Интересантно је, да је број и сразмера хонорациора у Суботици, а нарочито у Новом Саду, био осетно већи од оног у Сомбору, иако је Сомбор био седиште Бачко-бодрошке жупаније и центар коморског властелинства.

Од јужноугарских жупанија у Бачко-бодрошкој је било највише хонорациора. Рачунајући заједно са оним у слободним краљевским градовима, било их је укупно 328, што је знатно више него у Торонталској (60) и Тамишкој жупанији (89, заједно са Темишваром 129). Готово се подразумева да је већина (60\%) живела у градовима, близу $24 \%$ у варошима, а у селима само $16 \%{ }^{20}$

\section{Пољопривреда}

Економски односи и мрежа насеља Бачко-бодрошке жупаније били су знатно одређени њеним географским положајем, историјском прошлошћу и природним датостима.

Обрадиве површине чиниле су две трећине територије Бачко-бодрошке жупаније $\left(6.803 \mathrm{kм}^{2}\right)$. Од тога, $3.219 \mathrm{kм}^{2}$ биле су оранице, $2.078 \mathrm{kм}^{2}$ ливаде и пашњаци, 357 км $^{2}$ виногради и 1.148 км $^{2}$ шуме. ${ }^{21}$ Бачка је била позната по доброј, родној земљи, иако је у стварности квалитет и састав земљишта знатно варирао. Алмаш, Баја, Барачка, Јанковац, Мадараш, Моноштор и северни део Суботице простиру се на жутом песку који је првенствено погодовао виноградарству и сточарству. Насеља на широким плавним областима уз Дунав, попут Богојева, Бођана, Плавне, Вајске и Сонте имала су шалитрасту земљу средњег квалитета. Висораван Телечка је од чврстог леса, где су на појединим локацијама мештани дубили винске подруме на спрат, док је у долинама првокласно земљиште одлично родило. Првокласне оранице налазиле су се јужно од Фрањиног канала, где је и без ђубрења постизан десетоструки-дванаестоструки род. ${ }^{22}$ У првој половини 19. века

\footnotetext{
${ }^{20}$ Z. Györe, Gradovi i varoši Bačke, 69.

${ }^{21}$ Benda Gyula, Statisztikai adatok a magyar mezőgazdaság történetéhez 1767-1867, Budapest 1973, 106.

${ }^{22}$ E. Fényes, Magyarországnak s a hozzá kapcsolt tartományoknak mostani állapotja statisztikai és geographiai tekintetben, I-VI, Pest 1836-1840, 27-28.
} 
постојало је раширено уверење да се у целој Мађарској најквалитетније и највише житарица производи у Бачкој и Банату. Сходно томе, Бачко-бодрошка жупанија плаћала је и највише пореза (290 тзв. палатзиналних порти) у земљи. ${ }^{23}$

Уз обрадиве земљишне површине Бачка је обдарена и водотоковима: уз Дунав и Тису постојао је Фрањин канал, и поменуте водене површине играле су значајну улогу у робном и путничком промету, односно као покретачка снага водених млинова. Богатство рибом је било толико да се дешавало да после већих поплава за исхрану свиња у приобаљу Тисе користе рибу. ${ }^{24}$

Слично суседним жупанијама, у Бачко-бодрошкој је доминирала пољопривредна производња. Развијена је била земљорадња, као и сточарство, с тим да је нагласак све више падао на земљорадњу. У периоду 1790-1867. на нивоу земље примећује се готово двадесетпостотно повећање пољопривредних области на штету мочвара и шума. Тако је било и у Бачкој и у Банату, где су путем регулације тока река и изградње насипа знатне територије претворене у обрадива земљишта. ${ }^{25}$ Док је још почетком 18. в. доминирало екстензивно сточарство, двадесетих година 19. века бачке области је више карактерисала тенденција претварања пашњака у оранице и интензивна производња житарица. У овом смислу, у Бачкој су највише напредовали градови (у којима је 79,3\% свих земљишта била ораница), док су трговишта и села са својих $46,8 \%$, односно $48,2 \%$, заостајала за градовима. У складу са постојањем веома великог градског атара, Суботица је уз велике ораничне површине поседовала и другу по реду површину (после Сегедина) под пашњацима и ливадама од слободних краљевских градова Мађарске, а ни Сомбор није пуно заостајао. ${ }^{26}$

Виноградарство је у нашим областима имало првенствено функцију попуњавања породичног прихода, мада је његовом развоју до извесне мере допринео и општепознати лош квалитет бачванске пијаће воде. У структури бачких пољопривредних површина виногради су заступљени у сразмери нижој од земаљске, заправо, њихова сразмера је само у градовима достизала земаљски ниво. У три слободна краљевска града произведено је 43,5\% количине и 53\% вредности бачког вина. Сем Темерина, сва посматрана насеља су располагала виноградима, а близу четвртине пописаних старешина имала је винограде. У погледу укупне величине винограда међу бачким насељима поново се истичу Суботица и Сомбор, а налазе се и међу 4 града са највише винограда у Мађарској. Знатна је била још производња вина у Кули, Сенти, Бачкој Паланци, Бачкој Тополи и донекле у Бачу и Кањижи. Било је пуно и крчми: у Новом Саду 173, у Сомбору154 а у Суботици 104, са

\footnotetext{
${ }^{23}$ Државни сабор из 1832-1836. г. на Бачку жупанију разрезао је 290 палатиналних порти (E. Fényes, Op. cit., 44). Палатинална порта је била идеална мерна јединица базирана на финансијско-материјалној снази муниципија. Висину пореза утврђеног на Државном сабору, на основу броја палатиналних порти, разрезивали су на жупаније и градове. Жупаније су те суме на основу броја дика (пореске јединице) даље делиле на срезове, солгабирови на општине, а сеоске судије на појединачне пореске обавезе (Pomogyi László, Magyar alkotmány- és jogtörténeti kéziszótár, Budapest 2008, 349).

${ }^{24}$ E. Fényes, Op. cit., 36.

${ }^{25}$ G. Benda, Statisztikai adatok a magyar mezögazdaság történetéhez 1767-1867, Budapest 1973, 106, 117; A. Хегедиш, Литература прве половине 19. века о привреди Торонталске, Бачко-Бодрошке и Сремске жупаније, 118-119.

${ }^{26}$ Z. Györe, Gradovi i varoši Bačke, 99.
} 
укупним годишњим приходом од солидних 24.311 форинти. ${ }^{27} \mathrm{C}$ обзиром на нижи квалитет бачког вина, имућнији су га набављали из Барање, Срема или жупаније Толна. $^{28}$

Иако се тежња ка модернизацији назире такође у сточарству и у земљорадњи, ипак у случају земљорадње више знакова указује на свесну жељу за повећањем обима и квалитета производње: постепено се одустаје од тропољног плодореда, повећава се оријентација произвођача ка тржишту, ради се на одомаћивању све већег броја житарица, производњи индустријских и махунастих биљака; примећује се ширење производње кукуруза, све боље искориштавање плодних површина, итд. Подаци пописа из 1828. године сведоче о натпросечној продуктивности пре свега у Суботици, Сомбору, Бачкој Тополи, Кули и Станишићу, али и у другим бачким насељима. Најпознатији производ Бачко-бодрошке жупаније била је пшеница одличног квалитета. Од јужноугарских жупанија овде је произведено далеко највише житарица: у години пописа 2,9 милиона пожунских мерова (приближно130.000 тона), док је Торонталска била на другом месту са 1,6 милиона пожунских мерова. ${ }^{29}$

Обиму продукције житарица одговарао је и развој млинарства: 1828. г. у Бачкој је било близу четиристо млинова, а 1895. г. са 1.136 млинова Бачка је била на другом месту у земљи. ${ }^{30}$

Сточарство је било најинтензивније у околини Суботице и дуж Тисе, али било је развијено по територији целе жупаније. Подаци пописа говоре о десетинама хиљада свиња и стоке, а газде су пријавиле близу 80.000 коња и 190.000 оваца, а ово су само минималне бројке; у стварности их је било знатно више. Велики број коња је делом у вези са пространошћу ораничних површина, делом су коњи коришћени у превозу робе: било је доста желира који су коњима превозили робу за потребе других и на тај начин зарађивали за живот. ${ }^{31}$ у првој половини 19. века био је популаран узгој свилених чаура, пре свега код немачких газда.

Од пописаних старешина 40\% газда имало је коње, 25\% краве, $19 \%$ свиње, само $10 \%$ њих поседовало је овце, а свега $7 \%$ волове за вучу. Најбогатије газде нашли смо у Суботици, Сомбору, Сенти, Кањижи и Старом Бечеју. Међу њима нису били ретки они који су држали неколико туцета грла стоке и коња, док су у другим насељима породице располагале са по 3 грла. Овчарство је постајало све популарније, те су имућне газде држале своја стада често на закупљеним пашњацима. Према подацима пописа, у Новом Саду је већина газда-поседника располагала са 50-100 оваца, у Суботици са 40-50, а у Кањижи и Темерину по 20 30 , док је у осталим насељима карактеристично било држање по двадесетак оваца. Но, треба да се подсетимо да су управо у вези са стоком порески обвезници успевали да прикрију највише своје имовине, барем $30 \%$, а то важи пре свега за

\footnotetext{
${ }^{27}$ Исто, 196, 221, 223.

${ }^{28}$ А. Хегедиш, Успон градске привреде, 70.

${ }^{29}$ Z. Györe. Gradovi i varoši Bačke, 102-103.

${ }^{30}$ Исто, 128.

${ }^{31}$ На основу подата Земаљског пореског пописа из 1828, Архив Војводине, Збирка микрофилмова, Н 58-Н 90 .
} 
насеља са великим атарима, као што су Суботица, Сомбор, Кањижа, Сента. ${ }^{32}$

\section{Имовно стање опорезиваног становништва}

Када се бавимо анализом имовинског стања пописаног становништва, нарочито треба да имамо на уму већ помињане методолошке примедбе у вези са земаљским пореским пописом из 1828. године.

На посматраним насељима живело је укупно 63.216 лица подложних опорезивању. Њихово имовно стање веома је тешко проценити из више разлога, од којих је један од важнијих чињеница да нису пописана земљишта која су порески обвезници закупљивали, ремененцијалне земље и крчевине. Није нам познат тачан однос њихове величине према урбаријалним земљиштима, али из многих каснијих извора се види да је реч о веома значајним површинама: на земаљском нивоу у случају ремененцијалних земљишта тај однос се кретао од $20 \%$ до $50 \%$, а у случају крчевина приближно од $30 \%$ до изнад $100 \%$ величине урбаријалних земљишта! На територијама које су некад биле под османском влашћу и биле су запуштене, као што је Бачка или Банат, можемо очекивати да је било доста крчевина. Интензитет борбе за тим врстама земљишта и бројни извори из периода после 1849. г. сведоче о томе да су оне за егзистенцију сељаштва биле од пресудне важности: уколико су у питању били желири и ситнопоседници, та земљишта су била неопходна за пуко преживљавање, а уколико су у питању били имућнији сељаци, поменуте земље су служиле за продукцију вишкова за тржиште и осигурање бољег животног стандарда. ${ }^{33}$

Не познајемо у довољној мери имовно стање припадника неаграрних занимања (хонорациори, занатлије, трговци, крчмари, превозници, слуге, итд.). Поменути су и без земљишних поседа могли бити имућни или су барем били у стању да осигурају солидну егзистенцију за своју породицу, односно могли су поседовати мања или већа земљишта или винограде тек ради допуне својих прихода.

Попис на први поглед сведочи о солидним основама имовног стања: 69\% старешина у варошима имало је земљишни посед, а у градовима приближно половина њих. Чак $88 \%$ пописаних породица поседовало је ораницу, од њих 40,3\% имало је и ливаде, а 22,4\% уз оранице имало је ливаде и винограде. Преко 13\% старешина поседовало је само оранице, $11,8 \%$ оранице и винограде а $12 \%$ само винограде. $^{34}$

За посматрана насеља био је карактеристичан ситни и мали посед (до 15 хектара), какве је имало 96\% газда у варошима и $76 \%$ у слободним краљевским градовима. Док је у градовима било 511 пореских обвезника са поседима изнад 30 хектара, таквих смо у варошима пребројали само осморо. Највише газда се великим

\footnotetext{
${ }^{32}$ На основу података пописа, Архив Војводине, Збирка микрофилмова, Н 58-Н 64.

${ }^{33}$ Für Lajos, Jobbágyföld - parasztföld, y: Szabó István (yp.), A parasztság Magyarországon a kapitalizmus korában 1848-1914, I, Budapest 1972, 90, 94-100.

${ }^{34}$ На основу података пописа, Архив Војводине, Збирка микрофилмова, Н 58 - Н 64.
} 
поседима нашли смо у Суботици, Сомбору, Новом Саду, Сенти, Старом Бечеју, Кањижи и Кули.

Анализом података пописа могли бисмо закључити следеће. Апсолутни минимум за преживљавање савремене земљорадничке породице од 7-8 чланова значио је ситни посед од 2,2 хектара (1/8 кметовске сесије). Ко је поседовао мању ораницу, сасвим сигурно није био у стању да прехрани своју породицу. Наравно, породице које су располагале поседом од 2,2 хектара, или мало већим, имале су несигурну егзистенцију и да би са сигурношћу прехраниле своје најближе и евентуално платили пореске обавезе, купиле со, одећу, обућу и сличне најосновније потрепштине, морале су додатно радити као надничари, бавити се превозом, вучом лађа, рибарством, ситном трговином или занатом, евентуално и закупом земљу, итд. У бачким насељима је било доста старешина у овој категорији имовног стања (у градовима чак $30,1 \%$, у трговиштима 17,5\%). За нијансу боље услове живота су имали кметови са малим поседима $(2,2-7,4$ ха) - они су уз семење за сетву и прехрану могли располагати и извесним „вишковима“ од 50-60 пожунских мерова пшенице вредности 35-40 форинти, од чега су евентуално могли купити део најосновнијих неаграрних производа или су могли платити неке своје дугове. У случају слабијег рода чак је и њихова основна егзистенција могла доћи у питање. Прилична је била и њихова сразмера: у градовима $22 \%$ а у трговиштима $41 \%$ свих газда. Кметови са средњим поседима (7,5-15 ha) су већ били у повољнијој ситуацији, пошто су са својих ораница могли произвести 90-216 пожунских мерова вишка пшенице у вредности 55-133 форинте. У зависности од квалитета земљишта, примењених агротехничких метода и временских прилика, они су већ могли имати реалне вишкове за тржиште; евентуално ангажовати помоћну радну снагу или закупити још земљишта. Овој категорији је припадало $37 \%$ кметова у варошима и $23 \%$ кметова у градовима. Релативно велика сразмера $(24 \%)$ сељака у градовима припадала је категорији имућних сељака, док је таквих у варошима било мало (4\%). Они су поседовали више од 15 хектара оранице, што је у случају газде са 30 хектара значило 468 пожунских мерова вишкова вредних 290 форинти. Уз покривање животних и производних трошкова те газде су били у стању да купују или закупљују земљишта, да улажу у сточаратво, плате надничаре, купе бољи алат, итд. Оваквих породица највише је било у три слободна краљевска града Бачке, затим у Бачкој Тополи, Бачу, Кули, Станишићу и Темерину. ${ }^{35}$

Још једном бисмо скренули шажњу на то да је при горњој анализи узета у обзир само величина пописаних ораница, а знамо да је претежна већина газда располагала и ливадама, пашњацима, виноградима и баштама, односно разном врстом стоке и живине, што је свакако позитивно утицало на побољшање њиховог материјалног положаја. Обрађивањем крчевина и ремененцијалног земљишта они су могли чак дуплирати своје приходе. На крају бисмо могли закључити да је, на основу података пописа, земљорадња осигуравала континуално стабилну егзистенцију, а некад и одређену зараду најмање за 40\% кметова. Најтежа је била ситуација желира бескућника, који су имали веома мало или нимало земље. Њихов

\footnotetext{
${ }^{35}$ На основу података пописа, Архив Војводине, Збирка микрофилмова, Н 58 - Н 64.
} 
постотак се у посматраним насељима кретао у просеку око $12 \%{ }^{36}$

\section{Занатство}

У време наших пописа индустријска револуција још није започета у Мађарској. За њену економију је била карактеристична доминантно аграрна производња. Чак и 1845. г. постојало је свега 89 фабрика. Развој индустрије омогућен је укидањем феудалних стега, стварањем повољнијих кредитних услова, применом све већег броја техничких иновација и стварањем слободнијег тржишта радне снаге, после 1848 . године. ${ }^{37}$

Занатство је полет доживело раније, од последње трећине 18. века, од када су се осећале позитивне последице пораста становништва, ширења унутрашњег тржишта и повећања интензитета пољопоривредне производње. Док је у земљама круне Св. Стефана 1785. г. радио 30.921 занатлија, њихов број је приметно порастао до 1828. г. када је у ужој Мађарској (без Хрватске, Војне границе и Ердеља) број занатлија достигао цифру од 94.553, а 1846. било их је већ 233.324. Таква динамика пораста била је већа од ритма повећања броја становника, а нарочито је била изражена у оним областима где је сељаштво у растућој мери производило за тржиште. Производња за пијацу је захтевала све више рада, чиме се смањивало време расположиво за производњу потрепштина у кућној радиности, а с друге стране тај додатни напор сељацима је повећавао куповну моћ, у корист занатлија. Водило је то стриктнијој подели рада. У складу са повећаним потребама за услугама занатлија, растући број занатлија се насељавао у варошким насељима и селима, а тај процес није спречило ни отварање бројних продавница и трговина у истим местима. У Бачко-бодрошкој жупанији је, сем споменутих чинилаца, раст броја занатлија подстицао и промет на Фрањином каналу као и регулација водотокова и исушивање мочвара. ${ }^{38}$

Развијеност занатства и трговине је за целину Бачко-бодрошке жупаније било карактеристично у натпросечном нивоу. Такву констатацију потврђује велик број занатлија и шегрта, њихова широка географска распрострањеност, интензитет занатске делатности и диференцираност врсте заната. У жупанији је било 5.783 занатлије, од тога 1.783 радило је у градовима, 1.422 у варошима и 2.578 у селима. Ако њима додамо 1.135 шегрта у градовима (нажалост не знамо број шегрта у осталим насељима), број оних који су се бавили занатом приближава се цифри од 7.000 (са шегртима у варошима и селима, којих је свакако било, прелази 7.000). У Бачко-бодрошкој жупанији пописано је више занатлија него у било којој јужномађарској жупанији, штавише, у Бачкој је било занатлија у сваком месту, док их је у Торонталској жупанији било у 92\% и у Сремској жупанији у $60 \%$ насеља. Постојало је најмање 87 врста заната. Раширеност и бројност занатлија сведочи о

\footnotetext{
${ }^{36}$ Z. Györe, Gradovi i varoši Bačke početkom XIX veka, 83-86.

${ }^{37}$ Dóka Klára, A Dél-Alföldi iparosság struktúraváltása a feudalizmusból a kapitalizmusba való átmenet korában 1828-1870, 199-200.

${ }^{38}$ Tagányi Károly, Az 1828-as összeirás végleges eredményei, y: „Magyar Gazdaságtörténeti Szemle“, Budapest 1896, 210; Mérei Gyula (гл. ур.), Magyarország története 1790-1848, Budapest 1983, 371.
} 
томе да је у Бачкој постојала стална потреба за њиховим радом (иначе би потребе становника могле задовољити и постојеће продавнице). На овакав закључак упућује и податак пописа да је близу 66\% занатлија упражњавало свој занат током целе године и да је само $12 \%$ оних који су радили мање од пола године. Ово се односи на градске занатлије док је у варошима $32 \%$ радило целе године, $31 \%$ мање од годину дана, а 37\% од 6 до 9 месеци током године. Они који су радили мање од пола године приходе су допуњавали зарадом од виноградарства или земљорадње. ${ }^{39}$

Занатство је било развијено у Новом Саду, Суботици, Сомбору, Апатину, затим у Бечеју, Бездану, Кули, Сенти и Кањижи, док је изразито неразвијено било у Оџацима и Станишићу (35 и 31 занатлија). Док је на нивоу уже Мађарске на 111 становника долазио по један занатлија, у бачким градовима је тај однос био 40, а у трговиштима 62; у Будиму и Пешти 23 и 25, у Дебрецину 24, у Сегедину 30, Пожуну 34, а у Темишвару чак на сваких 14 становника по један занатлија. ${ }^{40}$

Од 150 врсте заната евидентираних у Мађарској, у варошима је пописано 51 , у градовима 87 , колико је постојало и у просечно развијеним градовима попут Сегедина, Арада, Сатмарнеметија, Кошица, Комарома, Естергома, итд. У градовима са натпросечно развијеним занатством било је присутно обично више од 90 врста заната. У Бачу смо запазили интересантан пример тржишно оријентисане занатлијске производње: од укупно 71 занатлије 31 се бави лончарством, а чак дванаесторо њих производњом лула. ${ }^{41}$

Уколико анализирамо структуру занатлија по занатској грани, видећемо да их је било највише заступљених у кожарској индустрији (1.180 мајстора), затим у текстилној и одевној индустрији (839 мајстора), па следи прехрамбена и хемијска индустрија (562 мајстора), на четвртом месту је грађевинска и дрвна индустрија (331 мајстор), мало је заостајала метална и метално-прерађивачка индустрија (300 мајстора), а најмање мајстора било је заступљено у занатима који су били веома специфични или везани за услужне делатности (укупно 149 мајстора), попут произвођача поклопца за луле или власуљара. У посматраним насељима било је највише чизмара (496), затим следе млинари (384), ћурчије (345), ткачи (322), кројачи (303), ковачи (143) и ципелари (125). Пописано је 48 професионалних рибара, 46 шеширџија, 37 златара, 18 стаклара, 6 књиговесца и по један ливач звона, оргуљар и мајстор за поплочавање улица. У односу на обим грађевинске делатности и бројне цигларе, чуди нас свега 5 евидентираних циглара. Није пописан ниједан поштански службеник, иако је у Бачкој у то доба било барем 17 поштанских постаја. Слично, на укупно 160.000 становника вароши и градова чини нам се малим број од 38 месара, 31 пекара или 34 бербера. С друге стране, на лоше путеве а велики обим превоза роба упућује бројка од чак 118 точкара, а вероватно је у вези са знатним обимом пољопривредне производње и превоза и већи број ужара (86). И опет, број лађара је нереално мали (13), па је могуће да се односи на број мајстора у бродоградњи, а не на оне који су били лично инволвирани у промет лађама: лађара,

\footnotetext{
${ }^{39}$ Z. Györe, Gradovi i varoši Bačke početkom XIX veka, 225-235.

${ }^{40}$ Eperjessy Gábor, A szabad királyi városok kézmüvesipara a reformkori Magyarországon, Budapest $1988,16$.

${ }^{41}$ Подаци пописа, Архив Војводине, Збирка микорфилмова, Н 82, Бач.
} 
помоћног особља, физичке радне снаге за утовар-истовар робе и за вучу бродова, итд. Није нам познат ни број крчмара, али ако узмемо у обзир да је само у три града била 431 крчма, можемо претпоствати да је та делатност упошљавала неколико стотина људи и у варошима. ${ }^{42}$

Што се тиче имовног стања занатлија, установили смо да је у посматраним насељима $58 \%$ занатлија имало своје куће и да је $37,2 \%$ градских и $47,5 \%$ варошких занатлија поседовало земљишта. У градовима њихов највећи део располагао је виноградом $(36,5 \%)$, односно ораницом и виноградом $(22,5 \%)$. У варошима $34 \%$ занатлија-поседника имало је оранице и винограде, а $33 \%$ само оранице. Највећим површинама земљишта, са највише слугу и шегрта, располагале су занатлије из прехрамбене индустрије. Најимућније занатлије су своје вишкове прихода улагали у куповину земље и кућа а неретко у трговину. ${ }^{43}$

\section{Трговина}

Француски ратови и почетак индустријске револуције у Западној Европи су на смени 18. и 19. века пресудно утицали на промене у трговачким пословима у Мађарској. Између осталог, промењена је извозна структура Угарске: уместо претежно стоке и вина све више су доминирале житарице и вуна, а главни извозни правац постала је Аустрија. Отпочео је увоз аустријских индустријских производа, а у Мађарској масовна пољопривредна производња за тржиште. У складу са овим променама променила се и трговачка мрежа Угарске и од тад се она ослањала на тржишне центре, систем недељних и годишњих вашара, на традиционалне трговце, печалбаре, на центре за сакупљање робе на већим властелинствима и продавнице. Иако је ова еластична и динамична трговачка мрежа, генерално, смањила дотадашњи значај вашара, вашари су још 1828. г. представљали доминантна места размене добара.

Паралелно са горе поменутим развојем мењали су се и чиниоци од пресудног значаја за развој градова; више то није био велики број становника, односно управне и културне функције, већ привредне функције и унутар њих трговина. Последица су да су неки раније цветајући и динамични градови изгубили своју привлачну снагу, и уместо њих су полет добила дотад мање значајна, у турско доба посустала или сасвим нова насеља. Те околности илуструју подаци из 1828: од укупно 138 тржишних центара само је 35 имало статус слободног краљевског града, а чак 102 насеља било је у рангу трговишта, бискупских градова, а постоји међу њима чак и једно село. ${ }^{44}$

У нашој области сем горе наведених чинилаца од одређујућег утицаја на развој трговине били су брз раст броја становништва, релативно добро имовинско стање, добра географска локација, близина државне границе као и повољни услови

\footnotetext{
42 Подаци пописа, Архив Војводине, Н 58-Н 64, Н 82-Н 86, Н 88, Н 90, Z. Györe, Gradovi i varoši Bačke, 225-235.

${ }^{43}$ Z. Györe, Нав. дело, 155.

${ }^{44}$ Bácskai Vera, Nagy Lajos, Piackörzetek, piacközpontok és városok Magyarországon 1828-ban, Budapest 1984, 52 .
} 
за речни транспорт робе (Дунав, Тиса, Фрањин канал). У насељима Бачко-Бодрошке жупаније пописано је 1.197 трговаца, што у односу на бројем становника, даје приметно већу вредност од земаљског просека. Док је у Мађарској у просеку један трговац долазио на 714 становника, у Бачкој је на сваких 370 становника долазио један трговац, у Сремској жупанији однос је био 417, а у Тамишкој $625{ }^{45}$

У три бачка града живело је 49\% трговаца Бачко-бодрошке жупаније. По броју трговаца Нови Сад је следио одмах после Будима и Пеште, са 403 трговца, у Бачкој на другом месту је Суботица са 96 пописаних трговаца, затим следе Сомбор, Сента, Бачка Паланка, Стари Бечеј, Кањижа и Кула. Најмање трговаца је било у Бачу, Оџацима и Бачкој Тополи. Четири насеља (Нови Сад, Сомбор, Сента и Кула) од свих посматраних насеља била су и тржишни центри, мада у различитом обиму и са различитим карактером. Раширеност бачке трговине долази до изражаја уколико је упоредимо са суседним областима: овде је у $83 \%$ насеља пописано трговаца, у Торонталској жупанији у 61\% насеља у Сремској у 49\% док их је у Вршачком срезу Тамишке жупаније у $27 \%$ места.

Најважнија трговачка роба била је пшеница. Из правца Баната, преко турскобечејске луке, годишње је извезено преко милион пожунских мерова пшенице. Из Бачке су извожене још веће количине где су уз три краљевска града важна места трговине била Кула, Сентомаш и Врбас, места уз Фрањин канал. У Бачко-бодрошку жупанију роба је стизала Дунавом, Тисом и Фрањиним каналом, а у Банат Тисом, Моришем и каналом Бегеј. ${ }^{46}$

Земаљски порески попис из 1828. г. пружа одличне могућности за проучавање привлачне снаге насеља: пописивачи су анкетирали становништво које место посећују ради размене добара. Вера Бачкаи (Vera Bácskai) и Лајош Нађ (Lajos Nagy) су сложеном анализом тих података моделирали градску мрежу Мађарске из аспекта гравитационе снаге поједини насеља. Одредили су колико становника посећује само једно одређено тржишно место (чиста област) и колико њих посећује више тржишних места (подељена област). На основу те анализе се показало да су у Бачкој тржишни центри Нови Сад, Сомбор, Сента и Кула, а у Банату Турски Бечеј, Вршац и Велики Бечкерек. Уколико упоредимо број становника појединих насеља и број становника који су гравитирали према том месту, можемо констатовати да су највећом специфичном привлачном снагом располагали Турски Бечеј, затим Кула, Сента, Сомбор и Нови Сад. Баја, Турски Бечеј и Нови Сад су имали трговину земаљског значаја, Сомбор и Вршац су ималу регионални а Кула и Сента локални значај. $^{47}$ Подаци, међутим, нису потпуни у случају Новог Саду, јер не садрже информације у вези са његовом привлачном снагом према Срему, а она је била битна.

Нови Сад је после Баје, било најзначајније трговачко средиште у Бачкободрошкој жупанији. Уз Бају, Веспрем, Шопрон и Турски Бечеј био је један од

\footnotetext{
${ }^{45}$ Z. Györe, Нав. дело, 167.

${ }^{46} \mathrm{~A}$. Хегедиш, Литература прве половине 19. века о привреди Торонталске, Бачко-Бодрошке и Сремске жупаније, 113.

${ }^{47}$ Z. Györe, Нав. дело, 162-164.
} 
најзначајнијих места за трговину житарицама. C обзиром на то да је добрим делом преко Новог Сада текао увоз турске робе у Мађарску, град је и због тога имао значај на земаљском ниво. ${ }^{48}$ У Новом Саду је произведено релативно мало житарица, те се трговало житарицама довезеним у град са стране. Истовремено, новосадски трговци су становништво околних бачких и сремских насеља снабдевали занатлијским производима, колонијалном робом, а у великој мери опскрбљивали су и посаду петроварадинске тврђаве. Приликом пописа новосадски градски оци су се жалили да од изградње Фрањиног канала трговина у Новом Саду назадује и да се заправо развијају само Тител, Бачко Градиште, Сентомаш, Бачка Паланка, Бач, Кула и Баја. Познајући бројност, диференцираност и материјалну снагу новосадских трговаца, можемо претпоставити да су њихове жалопојке биле претеране. ${ }^{49}$

Интересантан је случај Суботице: иако није имала значај у трговини на регионалном или земаљском нивоу, у њој је живело пуно трговаца. Величина атара Суботице, бројност становника, знатан обим и вишкови пољопривредне и занатске производње, солидно имовинско стање становника, сами по себи су учинили Суботицу интересантном за трговце. Слично, потражња коју је осигуравала бројност Суботичана стварала је услове за егзистенцију многим трговцима и занатлијама. Чињеница да је Суботица лежала далеко од водених саобраћајница такође је допринела томе да град не постане тржишни центар, штавише и њени становници одвозили су своје производе у Бају. ${ }^{50}$

\section{Саобраћајни услови}

Велики обим трговачког пословања нису могли умањити ни пословично лоши путеви. У то време у Бачко-бодрошкој жупанији није било ниједног каменог пута, што је изазивали пуно невоља у јесењим и зимским кишним периодима (1790. г. у Мађарској је било 770 км поплочаних путева, 1850. г. 1.750 км). ${ }^{51}$ Према мишљењу једног немачког путописца, путеви су преко јесени и зиме били лоши до те мере да је путовање лако могло доћи главе вучним воловима или коњима. Из тих разлога, у Бачкој су преферирали водене токове, којих је на срећу било довољно. Раније су за сувоземни транспорт озбиљне недаће стварале и подземне воде, а нарочито водена мрежа речице Мостонга. Ту ситуацију је поправила изградња Фрањиног канала и система мањих канала, који су с њим били повезани. Фрањин канал је повезивањем Дунава и Тисе од Бачког Моноштора до Бачког Градишта смањио и време пловидбе за три недеље, а трошкове у значајној мери. Његов значај потврђује и то да је у периоду 1802-1818. кроз канал прошло 15.660 лађа са више од 7 милиона пожунских мерова терета. Могућности за водени превоз су биле значајне и стога што је сувоземни превоз био сувише скуп, па су, примера ради до 1820-их година банатске житарице истиснуте из Италије. Најважније луке у Бачкој биле су у

\footnotetext{
${ }^{48}$ V.Bácskai, Városok és városi társadalom Magyarországon a XIX. század elején, Budapest 1988, 35.

${ }^{49}$ На основу података пописа, Архив Војводине, Збирка микрофилмова, Н 62, „Observationes”.

${ }^{50}$ Z. Györe, Нав. дело, 165.

${ }^{51}$ G. Mérei, Op. cit., 237.
} 
Баји, Апатину, Футогу, Турском Бечеју и Кули. Регулацијама тока реке Тисе, Саве, Драве, Купе, изградњом канала Бегеј, све веће области су укључене у систем воденог саобрађаја. ${ }^{52}$

Претежна већина бачких насеља је 1827/28. г. била стара свега 70-80 година и динамично се развијала. Подаци сведоче о томе да је стотинак година од ослобођења испод османске власти област веома успешно враћена у правну и друштвену структуру Угарске. Штавише, Бачка је по бројности становништва и по обиму пољопривредне производње постала једна од водећих области, а није заостајала ни по броју занатлија и трговаца. У том раздобљу, Бачко-бодрошка жупанија је личила на градилиште: настало је на десетине нових насеља, изграђено је близу 60.000 приватних кућа и бројне јавне грађевине, изграђен је Фрањин канал и радило се на исушивању мочварних области.

При томе, Бачка је располагала местима која су од суседних области имала знатно више становника. Она су се по динамици развоја, укључености у привредне токове земље и количини тржишних вишкова разликовала међусобно. Велика концентрација становника, материјалних добара, продукција за тржиште, знатнија друштвена и материјална диференцијација одликовали су првенствено градове, делимично вароши а најмање села.

Готово се искључиво радило о аграрним насељима у којима се занатство и трговина ослањали пре свега на потребе многобројних становника места. С друге стране, насеља која су остваривала значајне тржишне вишкове дала су јак полет трговачкој делатности. Иако о сувоземном и воденом саобраћају немамо податке у коришћеним пописима, узимајући у обзир велики обим трговински размене, морамо претпоставити да је приличан број породица био укључен у те делатности.

Могло би се приметити да на основу инфраструктуралне изграђености и спољашности улица, бројности модерних јавних зграда већина варошких насеља није личила на савремене европске градове и вароши. Притом би требало да имамо на уму две околности: да су ова насеља ипак била носиоци централних привредних, административних, образовних, културних или верских функција, односно да насеља на просторима на којима се ранија простирала османска власт и где су деценијама вођени тешки ратови не можемо упоређивати са градовима у срећним регијама Европе, које су избегле османску власт и деценијска па и вековна ратна пустошења. Заправо, оновремена власт је даривањем разних правних и економских привилегија управо градовима и трговиштима наменила улогу центара ревитализације некадашњих османских области.

\footnotetext{
${ }^{52}$ А. Хегедиш, Градска земьа и грађани, 42-42; А. Хегедиш, Литература прве половине 19. века о привреди Торонталске, Бачко-Бодрочке и Сремске жупаније, 113.
} 


\section{Извори и литература:}

Грађа пописа на основу VII законског члана Државног сабора Мађарске о ,земаљском попису с ииљем исправљања порти “, Архив Војводине, Збирка микрофилмова, Серија Н. Н 59 -Н 60: Суботица; Н 61-Н 62: Нови Сад; Н 63-Н 64: Сомбор; Н 82: Апатин, Бач; Н 83: Бездан; Н 85: Оџаци; Н 86: Кула; Н 88: Станишић; Н 89: Бечеј, Темерин, Б. Топола, Б. Паланка, Нови Футог; Н 90: Стари Футог, Кањижа, Сента, сумарне табеле Торонталске, Сремске и Тамишке жупаније.

Bácskai V., Városok és városi társadalom Magyarországon a XIX. század elején, Budapest 1988.

Bácskai V., Nagy L., Piackörzetek, piacközpontok és városok Magyarországon 1828-ban, Budapest 1984.

Benda Gy., Statisztikai adatok a magyar mezőgazdaság történetéhez 1767-1867, Budapest 1973.

Borovszky S., Bács-Bodrog megye története, I, Budapest 1909.

Čobanović K., Hegediš A., Demografska i agrarna statistika Vojvodine 1767-1867, Novi Sad 1991.

Dóka K., A Dél-Alföldi iparosság struktúraváltása a feudalizmusból a kapitalizmusba való átmenet korában, y: „Tanulmányok Csongrád Megye Történetéből“, XIII., Csongrád Megyei Levéltár, Szeged 1988, 199-262.

Fényes E., Magyarország geographiai szótára, I-IV, Pest 1851.

Fényes E., Magyarország leirása, I-II, Pest 1847.

Eperjessy Gábor, A szabad királyi városok kézmüvesipara a reformkori Magyarországon, Budapest 1988

Für L., Jobbágyföld - parasztföld, y: Szabó István (yp.), A parasztság Magyarországon a kapitalizmus korában 1848-1914, I, Budapest 1972.

Györe Z., Gradovi i varoši Bačke početkom XIX veka, Novi Sad 2007.

Mérei Gyula (гл. ур.), Magyarország története 1790-1848, Budapest 1983.

Nagy L., Notitae politico-geographico-statisticae inclyti Regni Hungariae partiumque adnexarum, I-II, Buda 1828-29.

Pomogyi L., Magyar alkotmány- és jogtörténeti kéziszótár, Budapest 2008.

Tagányi K., Az 1828-as összeírás végleges eredményei, y: „Magyar Gazdaságtörténeti Szemle”, Budapest 1896.

Попис становнштва, домаћинства и станова у Републици Србији 2011. године, Републички завод за статистику ISSN 0354-3641, Билтен - Републички завод, Београд 2011.

Ђере, 3., Демографски односи Војводине на основу пописа Лајоша Нађа из 1828. године, Зборник Матице српске за историју 46, Нови Сад 1993, 101-133.

Хегедиш, А., Градска земља и грађани, Домети, бр. 100-103, Сомбор 2000, 41-60.

Хегедиш, А., Литература прве половине ХІХ века о привреди торонталске, бачко-бодрошке и сремске жупаније, Зборник за историју, бр. 21, 1980, 109-133.

Хегедиш, А., Урбани преображај, Домети, бр. 100-103, Сомбор 2000, 84-102.

Хегедиш, А., Успон градске привреде, Домети, бр. 100-103,Сомбор 2000, 62-83.

Хегедиш, А., Управни, друштвени, духовни и културни центар, Домети, бр. 100-103, Сомбор 2000, 103-124. 


\title{
GYÖRE ZOLTÁN
}

\section{MARKET TOWNS OF BAČKA ACCORDING TO A LAND-TAX SURVEY OF 1828}

\begin{abstract}
Summary
The study relates to the demographic and economic characteristics of 3 cities and 13 towns in Bácska region according to the State Tax Census from 1828 and the population census of Ludovicus Nagy from 1827. It analysis the demographic, ethnic and religious characteristics of mentioned settlments. It covers some issues of social stratification, as well as the cities and towns agricultural production, possession situation, craftsmanship and trade characteristics.

Available data reveal that after the period of Turkish rule (1526-1699) the Bácska region was successfully reintegrated into the legal and social tissue of Hungary. Moreover, we can conclude that until 1828 Bács-Bodrog County, with its urban municipalities, became one of the most developed regions of the state in the sense of the intensity of agricultural production, crafts and the extent of trade, as well as one of the ethnically most complex areas of Hungary. The 1828 census analysis has made it clear that the most important role in this development had the three royal cities: Szabadka, Újvidék and Zombor and some of the towns as Zenta, Kúla, Kanizsa, Bácspalánka and Apatin.
\end{abstract}

Keywords: Habsburg Monarchy, Kingdom of Hungary, Vojvodina, demography, statistics, trades, merchants and mercantile activity, agricultural production, free royal towns, market centres. 